\title{
Sustainability indicators of the Brazil nut tree management
}

Indicadores de sustentabilidade do manejo da castanha-da-amazônia

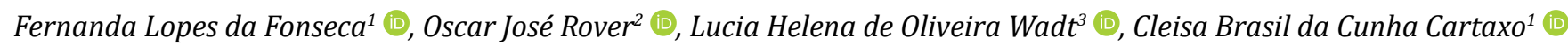

\begin{abstract}
A B S T R A C T
Brazil nut tree (Bertholletia excelsa Bonpl) management, is a traditional activity that plays a key role in the economy of forestbased Amazon communities and in the conservation of forests. Nevertheless, some threats and critical points related to sustainability indicate to the need for establishment of monitoring procedures that can assist in the management of this natural resource. The overall aim of the research was to evaluate the MESMIS method as a tool to support the participatory definition of sustainability indicators to monitor Brazil nut management, and the viability of Brazil nut harvest over time. For that, we carried out a case study in the Porvir Community, RESEX Chico Mendes, Acre State (Brazil), aiming to integrate the perceptions of Brazil nut harvesters, researchers, managers, and technicians to define the indicators. The result was the generation of 18 strategic indicators to assess sustainability in the environmental, technical-economic and social dimensions. Assessment parameters, representing conditions that must be achieved for system sustainability, were collectively defined for each indicator. The main critical values attributed in the evaluation of the indicators are related to Brazil nut commercialization to intermediaries and oscillation in the annual fruit production. The use of the MESMIS method was considered appropriate to the studied context and can be recommended to similar non-timber forest product management systems.
\end{abstract}

Keywords: extractivism; sustainability indicators; community management; mesmis method.

\begin{abstract}
RE S U M 0
O manejo da castanheira-da-amazônia (Bertholletia excelsa Bonpl.) é uma atividade tradicional, chave para a economia de milhares de famílias extrativistas da Amazônia e para a conservação das florestas. Algumas ameaças e pontos críticos relacionados à sustentabilidade da atividade apontam para a necessidade de se estabelecerem procedimentos de monitoramento que possam auxiliar na gestão desse recurso natural. O objetivo deste trabalho foi avaliar o método Marco para a Avaliação de sistemas de Manejo de Recursos Naturais Incorporando Indicadores de Sustentabilidade (MESMIS) como ferramenta de apoio à definição participativa de indicadores para a avaliação da sustentabilidade do manejo de castanhais nativos e da viabilidade do extrativismo da castanha ao longo do tempo. Para tanto, realizou-se um estudo de caso na Comunidade Porvir, Reserva Extrativista Chico Mendes, Acre, onde se buscou integrar as percepções de extrativistas, pesquisadores, gestores e técnicos sobre o assunto. O resultado foi a geração de 18 indicadores estratégicos para a avaliação da sustentabilidade nas dimensões ambiental, técnico-econômica e social, definindo-se coletivamente parâmetros de avaliação para cada indicador. Os principais valores críticos atribuídos na avaliação do estudo de caso foram relacionados à questão da comercialização da castanha para atravessadores e à oscilação na produção anual de frutos. O emprego do método MESMIS foi considerado adequado ao contexto estudado, de modo que pode ser recomendado e adaptado ao manejo de outros produtos florestais não madeireiros.
\end{abstract}

Palavras-chave: extrativismo; indicadores de sustentabilidade; método mesmis; manejo comunitário.

\footnotetext{
${ }^{1}$ Empresa Brasileira de Pesquisa Agropecuária - Rio Branco (AC), Brazil.

${ }^{2}$ Universidade Federal de Santa Catarina - Florianópolis (SC), Brazil.

${ }^{3}$ Empresa Brasileira de Pesquisa Agropecuária - Porto Velho (RO), Brazil.

Correspondence address: Fernanda Lopeas da Fonseca - Rodovia BR-364 - Km 14 (Rio Branco/Porto Velho) - Caixa Postal: 321 - CEP: $69900-970$ Rio Branco (AC), Brazil. E-mail: fernanda.fonseca@embrapa.br

Conflicts of interest: the authors declare no conflict of interest.

Funding: Empresa Brasileira de Pesquisa Agropecuária (Embrapa).
}

Received on: 08/20/2020. Accepted on: 06/16/2021

https://doi.org/10.5327/Z21769478889

This is an open access article distributed under the terms of the Creative Commons license. 


\section{Introduction}

The Amazon rainforest is the world's largest tropical forest, with about $52 \%$ of its territory protected as conservation units or indigenous lands. These areas act as a buffer for external pressures of deforestation and expansion of the agricultural frontier, contributing significantly to ensuring biodiversity, reducing carbon emissions, and mitigating climate change. The Brazilian Amazon alone fixes roughly 30\% of all carbon stored in protected natural areas and indigenous lands throughout the biome (Walker et al., 2020).

The production of Brazil nuts is directly related to the conservation of the Amazon Forest. The species Bertholletia excelsa is an imposing tree in tropical forests and produces Brazil nuts, which is collected almost exclusively in native forests. Currently, Brazil nuts is considered one of the most important non-timber forest products in the world (Gardner and Costi, 2014).

Most Brazil nuts are produced in conservation units, primarily by traditional peoples and communities, including extractivists, indigenous people, and quilombolas, combining income generation and biodiversity conservation (Picanço and Costa, 2019; Silva et al., 2020).

Over the past three decades, Brazil nuts have emerged as a key product in the Amazonian extractive economy, promoting food security and ensuring the livelihoods of traditional populations (Kainer et al., 2018).

In the state of Acre, Brazil, despite the well-structured production chain and the valorization of Brazil nuts in the market, the sustainable management of the activity faces threats and critical points, which require studies for a better understanding. Some of these challenges concern the socio-environmental crisis, climate change, constant threats of deforestation, and forest fires, as well as the conversion of forest areas into pastures in the Amazon. Other concerns refer to oscillations in fruit production of Brazil nut trees in critical years, price fluctuations, and market speculations, deficiency of public policies for the sector, as well as the fragility of the social and governance dynamics that involve these management systems (Brose, 2016; Cartaxo et al., 2016; Wadt et al., 2016; EMBRAPA, 2017; Mascarenhas et al., 2018).

These socioeconomic and productive challenges for Brazil nut harvests by traditional populations require community management strategies to assess and monitor the sustainability of these production systems. These strategies allow understanding interrelationships, predicting risks, and proposing improvements for the resilience of the system.

This work evaluated the Marco para la Evaluación de Sistemas de Manejo de los Recursos Naturales Incorporando Indicadores de Sustentabilidad method (MESMIS) as a support tool for the participatory definition of indicators to assess and monitor sustainability in Brazil nut stands management, based on a case study carried out at RESEX Chico Mendes in the state of Acre.
General aspects of sustainability indicators in natural resource management

Since the United Nations Conference on Environment and Development "Rio 92" and the elaboration of Agenda 21, the need to develop indicators capable of assessing sustainability has been discussed in the political and academic spheres. According to Caporal et al. (2010), based on the institutionalization and popularization of the sustainable development discourse, the search for methodologies that allow measuring sustainability and, consequently, indicating ways to minimize social problems intensifies on the scientific, ecological, and economic agenda promoted by anthropic action in agroecosystems and by unequal sociopolitical relations regarding the appropriation of nature.

In general, "sustainability indicators intend to inform concisely about a certain state or a certain condition of a system of interest (an agroecosystem, for example). Sustainability indicators are taken, therefore, as decision-making instruments to improve the use of the environment" (Schlindwein, 2010, p. 88).

Gallopín (1996) states that the most important characteristic of an indicator is its relevance to policies and the decision-making process, and social actors involved in the process have considered the indicator's relevance to be representative.

Sustainability indicators are defined as the synthesis and interpretation of a set of information that indicate trends in behavior and help in the development of strategies to improve the human-nature relationship. These indicators allow quantifying, analyzing, and transmitting information in a simple way, as well as informing about the achievement of sustainability in different dimensions. Therefore, it is possible to monitor progress toward achieving the goals set, preventing economic, environmental, and social losses (Hammond et al., 1995; Bellen, 2006; Melane-Lavado and Álvarez-Herranz, 2018).

In this context, sustainability indicators can and should be widely used as a management tool in projects and processes linked to the management of natural resources, as they allow diagnosing, monitoring, evaluating, and planning methods, guiding new actions and investments for local development and for the creation of public policies (Vivan and Floriani, 2001; Steenbock et al., 2013).

However, Schlindwein (2010) states that the adoption of sustainability indicators in the management of natural resources only provides concrete changes if the indicators are developed through processes that involve social learning and joined actions between the different social actors.

According to Marques et al. (2003), indicators should:

- be applicable to many systems;

- be sensitive to system changes;

- be measurable and easy to measure;

- be easy to obtain and low cost;

- allow cross-checking with other indicators;

- be conceived with the participation of local population, at least at a property level of measurements. 
The use of the MESMIS method is highlighted in agroecology and small-scale natural resource management, mainly because this method has a flexible operational structure, allowing a "bottom-up" approach (involving different social actors, especially farmers) in the sustainability assessment process and proposing a cyclical assessment process (Cândido et al., 2015; Loureiro et al., 2020). These differentials allow using the method in different social and productive realities. According to Loureiro et al. (2020), over a hundred scientific papers on MESMIS have already been published, which document case studies applied to different productive activities (mainly agriculture and livestock) in different parts of the world.

\section{Material and Methods}

The MESMIS method for evaluating natural resource management systems

The MESMIS method was developed in Mexico during the 1990s and has been extensively tested in different geographic areas, mainly in South America, North America, and Europe. MESMIS presents a path to determine, read, and interpret sustainability indicators with a systemic focus. It also provides practical and flexible orientation for adaptations in different contexts, based on a participatory and interdis- ciplinary approach (Masera and López-Ridaura, 2000; López-Ridaura et al., 2002; Astier and Hollands, 2007; Astier et al., 2012).

The MESMIS framework (Figure 1) was developed by critically integrating concepts on sustainable development, sustainability, systemic approaches, natural resource management, sustainability assessment, and sustainability indicators (Masera et al., 1999; López-Ridaura et al., 2002).

Table 1 presents the definition of Masera et al. (1999) for the general attributes, which were theoretically conceived from fundamental systemic properties linked to different aspects for a management system to be considered sustainable.

\section{Case study at RESEX Chico Mendes}

\section{Study site}

The study was carried out in the municipality of Epitaciolândia, Chico Mendes Extractive Reserve (RESEX), Acre State, Brazil, in partnership with the community of Wilson Pinheiro Base Center (Community Porvir) (Figure 2). The nucleus aggregates 36 families and the total area of the community comprises 11,500 ha (Acre, 2012). The exploratory stage of the research began in January 2019 and data was collected between May and June 2019.

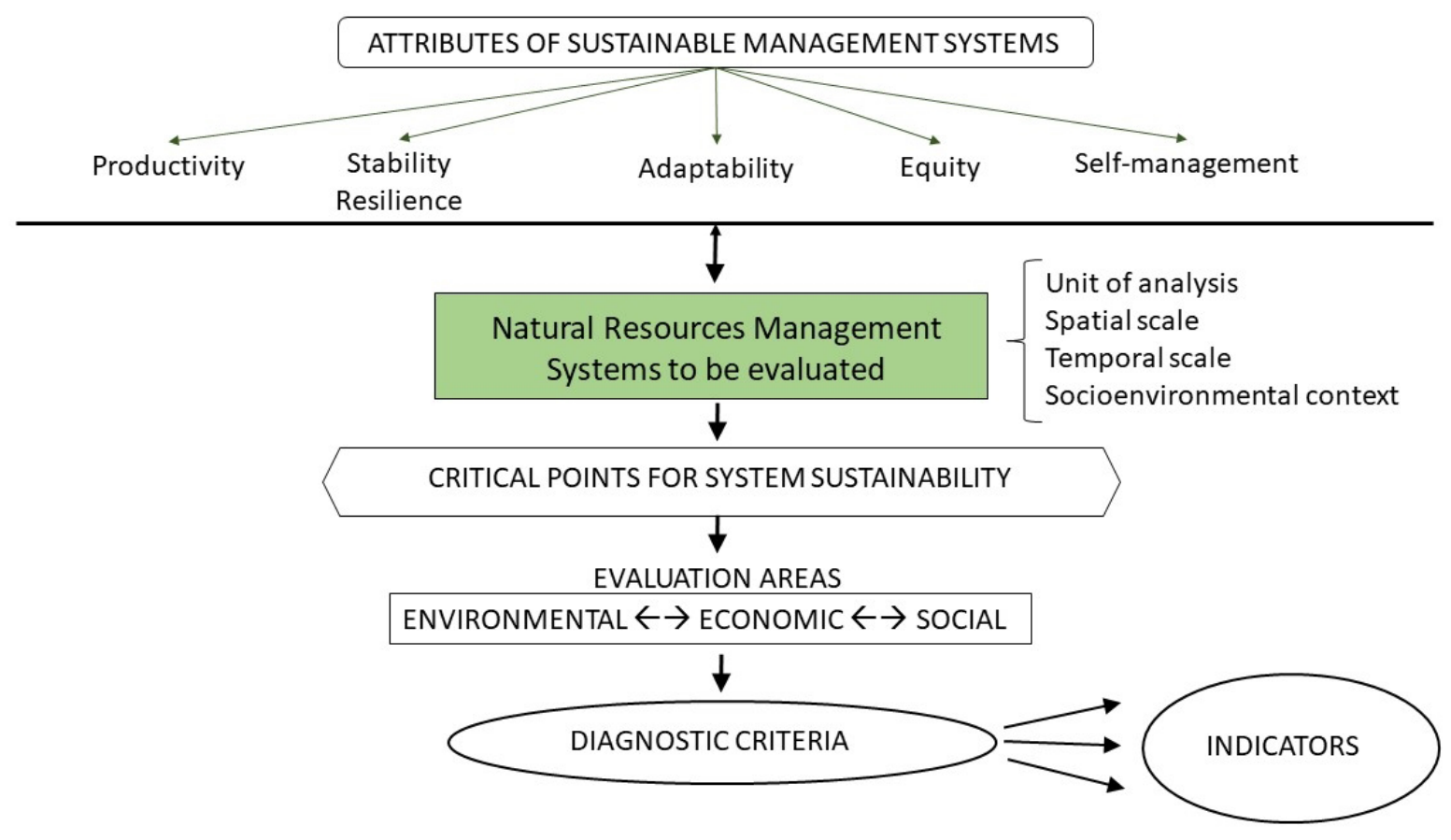

Figure 1 - The MESMIS method framework: linking sustainability attributes to indicators.

Source: translated from Masera et al. (1999). 
Table 1 - General attributes for sustainable management systems.

\begin{tabular}{|l|l|}
\hline Productivity & $\begin{array}{l}\text { Agroecosystem capacity to provide the required level } \\
\text { of goods and services. Represents the attribute value } \\
\text { (income, earnings, etc.) at a given time. }\end{array}$ \\
\hline $\begin{array}{l}\text { Stability and } \\
\text { Resilience }\end{array}$ & $\begin{array}{l}\text { Interconnected attributes relate to the system's ability } \\
\text { to ensure a state of dynamic equilibrium, maintaining } \\
\text { its productive capacity in face of normal environmental } \\
\text { changes (stability) or after suffering severe or extreme } \\
\text { disturbances (resilience). }\end{array}$ \\
\hline $\begin{array}{l}\text { Adaptability } \\
\text { or Flexibility }\end{array}$ & $\begin{array}{l}\text { System's ability to find new levels of balance and to continue } \\
\text { offering its benefits in the face of long-term changes in } \\
\text { the environment (such as new economic or biophysical } \\
\text { conditions). This attribute also refers to the ability to } \\
\text { actively search for new levels or production strategies. This } \\
\text { concept ranges from aspects related to the diversification } \\
\text { of activities or technological options to processes of social } \\
\text { organization and training of human resources. }\end{array}$ \\
\hline Equity & $\begin{array}{l}\text { System's ability to fairly distribute, both intra and } \\
\text { intergenerationally, the benefits and costs related to the } \\
\text { management of natural resources. }\end{array}$ \\
\hline Self- & $\begin{array}{l}\text { System's ability to regulate and control its interactions } \\
\text { with the outside world. It includes the organizational } \\
\text { processes and mechanisms of the socio-environmental } \\
\text { system to endogenously define its own objectives, } \\
\text { priorities, identity, and values. }\end{array}$ \\
\hline management
\end{tabular}

Source: translated from Masera et al. (1999).

\section{Data collection}

The research had a descriptive and analytical methodological character, with a quali-quantitative approach, prioritizing the participation of extractivists (López-Ridaura et al., 2002; Gomes, 2010). The premise for constructing the indicators was based on a "bottom-up" approach. After obtaining the necessary authorizations to conduct the research, the field trips were carried out. This research was approved by the Ethics Committee for Research with Human Beings of Universidade Federal de Santa Catarina (CEPSH-UFSC) through process No. 3.344.855/2019, as well as by ICMBio through the project submission on the platform of the System of Authorization and Information on Biodiversity (SISBIO - authorization No. 681441 , issuing date 03/29/2019).

The sustainability criteria and indicators were defined by the evaluation cycle proposed by MESMIS (Figure 3), with adaptations to the studied context inspired by other studies involving the generation and use of indicators with agro-extractivists (Vivan and Floriani, 2001; Steenbock et al., 2013).

The study was conducted according to the following steps:

- Step 1) Characterization of the management system studied, with its main socioeconomic aspects, based on a literature review and document analysis;

- Step 2) Participatory diagnostic workshop at the community aimed at: understanding the harvesters' perception on sustainability and aspects that define a "good" Brazil nut management system, from production to marketing; critical points of the management system, that is, aspects that limit or strengthen the production system capacity to sustain itself over time;

- Step 3) Systematization of an initial list of indicators from the following sources: aspects that define a good Brazil nut management system, according to the knowledge of harvesters; matrix of critical points; MESMIS framework (Figure 1); and information collected in step 1;

- Stage 4) Semi-structured interviews with different social actors interested in the management of native Brazil nut trees (researchers, RESEX manager, technicians, and harvesters), aimed at selecting strategic indicators from the initial list of indicators defined in stage 3. During the interviews, parameters were also defined to evaluate each indicator, according to the knowledge of the interviewees, assigning scores from 1 (one) to 10 (ten), where 10 represents the ideal condition for system sustainability; 5 represents an acceptable condition; and 1 represents an undesirable condition. The parameters constructed allowed evaluating indicators through the scores. In the end, 18 strategic indicators were selected to assess sustainability in the environmental, technical-economic, and social dimensions;

- Step 5) Assessment workshop in the community participating in the study. In this step, four Brazil nut stands were selected to apply the indicators, based on the scores defined in step 4;

- Step 6) Systematization and integration of data obtained in the field, using radial type graphics, examining the relationships between indicators (synergies and trade-offs).

The data collected and analyzed were used to describe conclusions and recommendations upon completion of the first evaluation cycle.

A volunteer group of 10 harvesters participated in the workshops, belonging to four different Brazil nut stands (productive units): Boa Água, Morada Nova, São José, and Encontro.

\section{Results and Discussion}

\section{Characterization of the management system studied}

Residents of the Community Porvir traditionally harvest Brazil nuts, rubber, açaí, bacaba, patoá, vegetable oils, as well as hunt, fish, and plant crops for subsistence. Some crops grown are rice, beans, corn, cassava (for flour production), banana, and other fruits. They also raise animals such as dairy and beef cattle, chicken, duck, pigs, fish, sheep, buffaloes, and horses. The main products commercialized are:

- Brazil nuts and latex;

- cassava, banana, rice, and corn;

- chicken, beef cattle, and swine. Income to the community is generated from extractivist activities, followed by agriculture and livestock (Acre, 2012). 

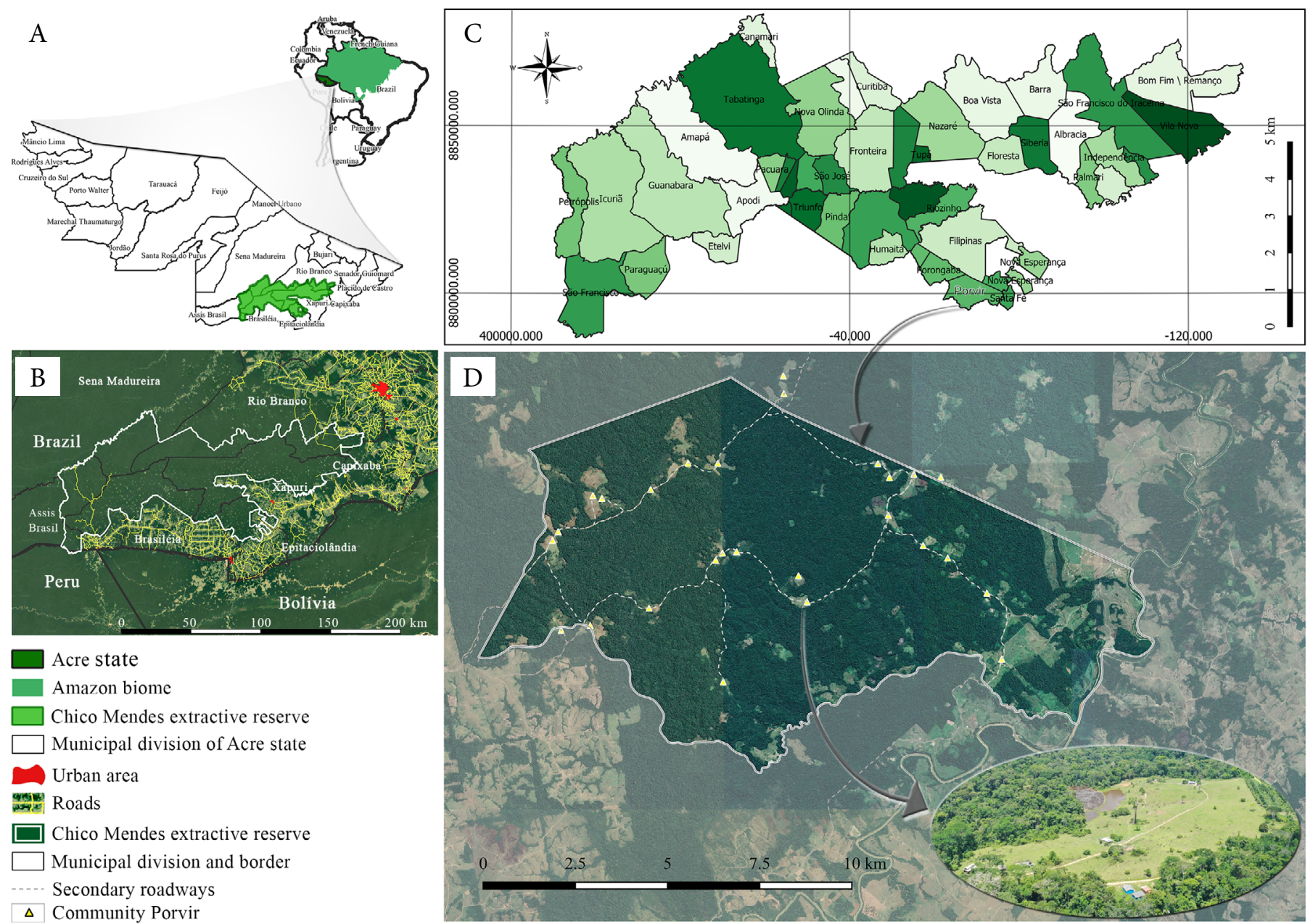

Figure 2 - Study site. (A) location of the Acre State and RESEX Chico Mendes; (B) area of RESEX Chico Mendes and municipalities included; (C) geopolitical division of rubber plantations of RESEX Chico Mendes; (D) highlight of Seringal Porvir area with a satellite image superimposed on the map with an aerial photo of the Boa Água site, location of the Wilson Pinheiro base nucleus.

Source: own data. Graphic design at Embrapa Acre. Google Satellite Images, 2017.

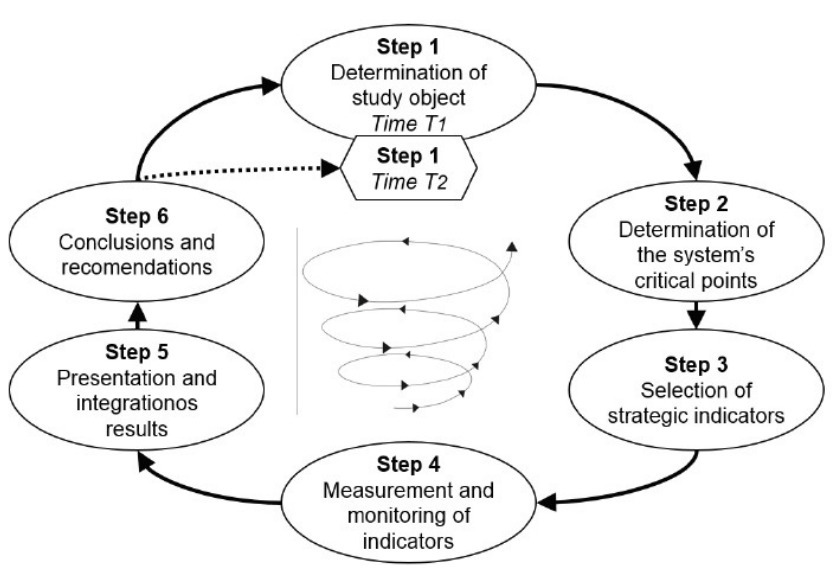

Figure 3 - MESMIS method evaluation cycle. Source: translated from Masera et al. (1999).
The field research showed that the income from the Brazil nut management constitutes the main financial source of families in the community, accounting for more than $40 \%$ of the annual income of the harvester's families participating in this study.

This result corroborates the study of Duchelle et al. (2014), who reported that the Brazil nut harvest accounts for $45 \%$ of the net income of families in the Western Amazon.

Figure 4 shows the traditional agro-extractivist management system of community residents, similar to practices at RESEX Chico Mendes, where production units include various components and subsystems (forest, agricultural, and animal). The dynamic nature of agroecosystems, which are constantly responding to internal and external changes, are highlighted (Masera et al., 1999).

Figure 5 shows the main timeframes that somehow affected the management of Brazil nut in the community, according to the har- 
vesters participating in the diagnostic workshop held during the field phase of this research.

Community residents emphasized the foundation in 1993 and bankruptcy in 2004 of the Agroextractive Cooperative of Epitaciolândia and Brasileia Producers (Cooperativa Agropecuária de Epitaciolândia e Brasileia - CAPEB).

CAPEB was founded with strong participation from the social movement of rubber tappers and even operated a nut processing plant in Brasiléia, provided by the state government of Acre in 2006. Due to internal management problems, the cooperative was unable to sustain the plant operation and cooperative producers, including those from the Community Porvir, had to pay the debt with the production of Brazil nuts at the time, which has been a factor of resistance to an initiative of a new community in cooperativism (Simoni, 2009).

More recently, in 2017, harvesters highlighted the construction of two community warehouses for Brazil nuts, with resources from the State Government, through an agreement with the Inter-American Development Bank (IDB).

Another milestone for the community was the approval of the Project "Castanhal - sustainable use of sociobiodiversity", with resources from the Amazon Fund, managed by the Banco do Brasil Foundation (Fundação Banco do Brasil - FBB), approved in the Ecoforte Extractivismo public selection for associations of extractive activities in federal protected areas. This was the first project of this type managed by the local association, representing a new experience for the community, which also relies on the Bem Diverso Project as a partner for administrative and operational support. This project develops actions for the conservation of biodiversity and sustainable management of natural resources in forest landscapes and agroforestry systems in three Brazilian biomes (Amazon, Cerrado, and Caatinga) in partnership between the Brazilian Agricultural Research Corporation (Empresa Brasileira de Pesquisa Agropecuária - Embrapa) and the United Nations Development Program (UNDP), with resources from the Global Environment Facility (GEF).

Unveiling sustainability with harvesters: descriptors of a "good" management system

Table 2 presents the descriptors of a "good" Brazil nut management system according to the perspectives of harvesters. The values in parentheses represent the number of answers given by the participants in the diagnostic workshop for the same descriptor, relativized as a percentage, and the total grouped by the sustainability attribute.

There is a prioritization of descriptors related to the attributes of adaptability and self-management, although the descriptor "good production" was the most cited among the total responses. The existence of very objective descriptors characterizes a good management system,

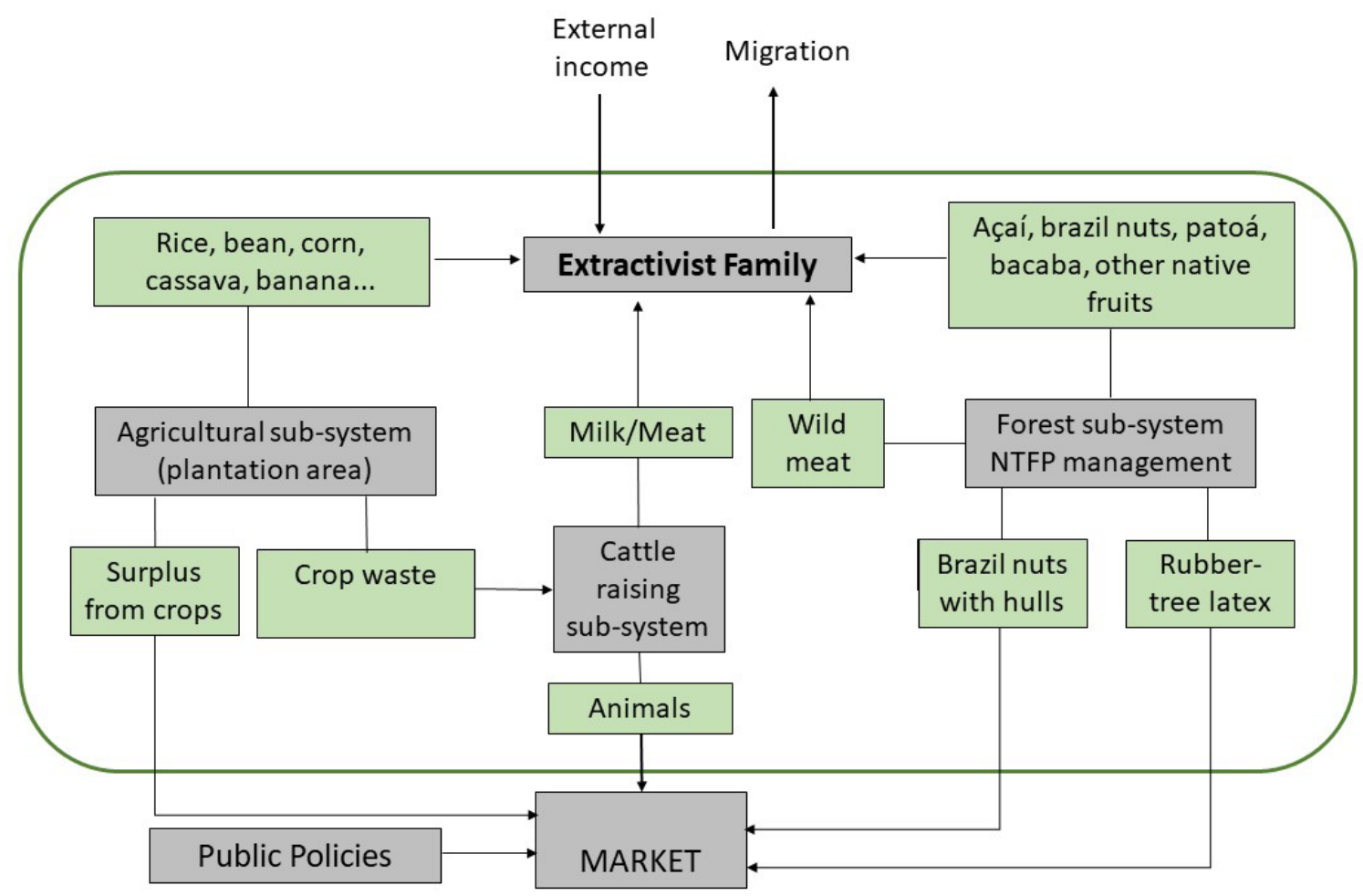

Figure 4 - Flowchart of the traditional agro-extractivist system in the Community Porvir, RESEX Chico Mendes, Acre State, Brazil.

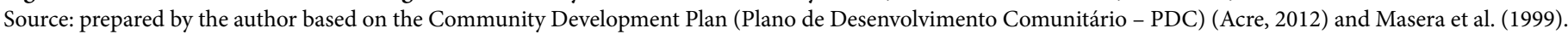




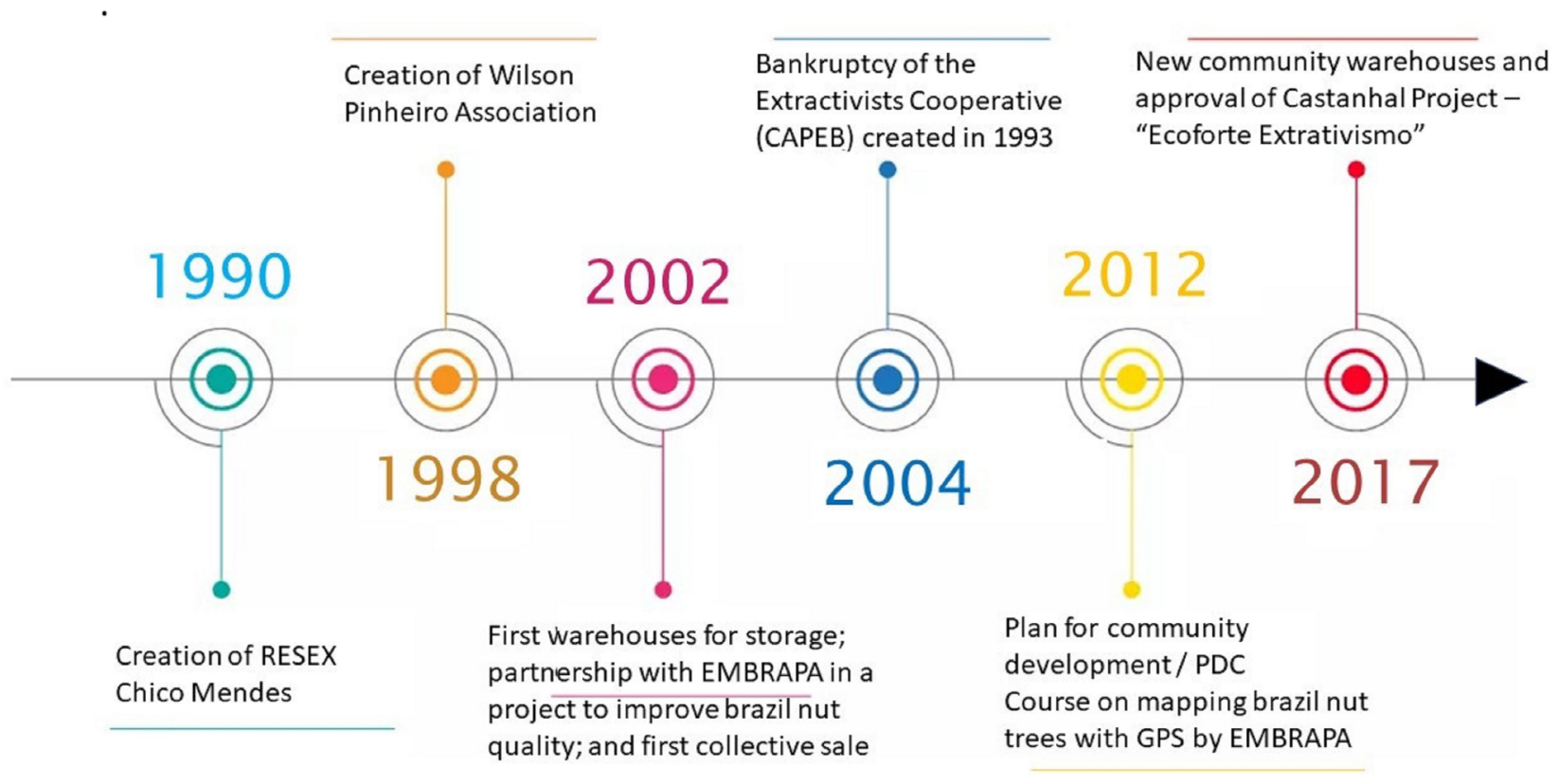

Figure 5 - Brazil nut Management timeline, Community Porvir, RESEX Chico Mendes - Acre State, Brazil. Source: prepared by the author based on data collected in the research.

even when observed from the logic of scientific knowledge. In addition, the ecological knowledge of harvesters is evidenced by the high relevance of descriptors for the stability of Brazil nut tree populations, such as the presence of dispersers and pollinators, for example bumble bees (Xylocopa spp.), as well as the existence of regeneration (young Brazil nut trees). This knowledge is also expressed in the social and economic dimensions, demonstrating a capacity for systemic vision.

Table 3 shows the matrix of limiting and strengthening points built from the diagnostic workshop.

The low productivity of Brazil nuts trees in recent years is one of the main limiting points pointed out by harvesters, due to ecological and climatic factors, such as the perception of the senescence of Brazil nut trees and the great droughts in Acre State in 2005 and 2017.

In recent decades, several studies have investigated the impacts of the intensity of Brazil nut harvest on the stability of managed populations. Peres et al. (2003) studied 23 populations of the Brazil nut species in the Brazilian, Peruvian, and Bolivian Amazon and concluded that the hunting of natural dispersers (such as agouti) and overexploitation of fruits in some regions directly reduced the natural regeneration of $B$. excelsa species.

Recent studies (Wadt et al., 2005, 2008) have challenged some of the hypotheses presented by Peres et al. (2003) in Acre. These investigations demonstrated a condition of dynamic equilibrium in the pop-
Table 2 - Descriptors of a "good" Brazil nut management system cited by harvesters grouped by general sustainability attributes according to the MESMIS Method framework.

\begin{tabular}{|l|l|}
\hline Attributes & \multicolumn{1}{c|}{ Descriptors } \\
\hline Adaptability (41) & $\begin{array}{l}\text { Nut transport tracks (4); well-kept Brazil nut trees (5); } \\
\text { access facilities (2); cleaning nut trees and removing } \\
\text { vines (7); cleaning peaks (4); mapping Brazil nut } \\
\text { trees (9); differentiated market (2); national and } \\
\text { international markets (2); partnerships (2); harvest } \\
\text { planning (2); use of good management practices (4) }\end{array}$ \\
\hline $\begin{array}{l}\text { Self-management } \\
\text { (21) }\end{array}$ & $\begin{array}{l}\text { Family warehouse for storage (2); good communication } \\
\text { (2); good organization (4); know production of Brazil }\end{array}$ \\
$\begin{array}{l}\text { nuts (2); quality nuts for good sales (9); vehicle to } \\
\text { transport the nut (2); direct sales (2). }\end{array}$ \\
\hline Productivity (18) & $\begin{array}{l}\text { Good production (11); good income to the producer } \\
\text { (4); production monitoring (2); quantity and quality } \\
\text { of nut trees (2) }\end{array}$ \\
\hline Equity (11) & $\begin{array}{l}\text { Women participating in harvest and income (2); fair } \\
\text { price and financial return (9) }\end{array}$ \\
\hline $\begin{array}{l}\text { Stability } \\
\text { and resilience (9) }\end{array}$ & $\begin{array}{l}\text { Absence of use of poisonous chemicals in Brazil nut } \\
\text { stands and surrounding areas (2); presence of agouti } \\
\text { - Dascyprocta spp. (2); presence of bumble bees (4); } \\
\text { presence of young Brazil nut trees (2) }\end{array}$ \\
\hline
\end{tabular}

Source: elaborated by the authors from data collected in the research. 
Table 3 - Matrix of limiting and strengthening points in the Brazil nut management, Community Porvir, RESEX Chico Mendes - Acre State, Brazil.

\begin{tabular}{|c|c|c|}
\hline Dimension & Limiting points & Strengthening points \\
\hline \multirow{3}{*}{ Environmental } & Use of pesticides around RESEX & Biodiversity richness \\
\hline & Deforestation & \multirow{2}{*}{ Presence of agouti and other rodents (nut dispersers) - fauna richness } \\
\hline & Weaknesses in RESEX management system & \\
\hline \multirow{3}{*}{$\begin{array}{l}\text { Technical- } \\
\text { economic }\end{array}$} & \multirow{3}{*}{$\begin{array}{l}\text { Sale to intermediaries } \\
\text { (no commitment to the community) }\end{array}$} & High market demand \\
\hline & & Mastery of Best management practices for Brazil nut \\
\hline & & Partnerships: Embrapa, Bem Diverso Project/UNDP, Ecoforte Extractivism \\
\hline $\begin{array}{l}\text { Social } \\
\text { (cultural and } \\
\text { political) }\end{array}$ & Lack of training - knowledge of the proper use of RESEX & Extractive Culture \\
\hline
\end{tabular}

Source: elaborated by the authors from data collected in the research.

ulations studied, according to the reverse-J pattern, in the frequency distribution of Brazil nut trees by diameter class. According to the authors, this structure suggests healthy demographic populations with capacity for self-regeneration.

Ribeiro et al. (2014) also demonstrated a positive correlation between nut extraction by traditional populations and the stability of managed tree populations. The authors studied Brazil nut trees under different harvesting intensities in southern Pará. Scoles and Gribel $(2011,2015)$ studied population ecology and regeneration of Brazil nut trees in the Madeira and Trombetas River basins. These studies showed that the regeneration rates of Brazil nut trees are higher in managed forest environments.

Zuidema and Boot (2002) used matrix models and concluded that two populations of Brazil nut trees managed in Bolivia remain stable, even under a harvest intensity of $93 \%$ of fruits. Bertwell et al. (2018) conducted a population modeling study based on data from 14 years of research in two managed areas in Acre State (Brazil) and concluded that, instead of concentrating on the fate of most of the seeds produced, the most pressing risk to $B$. excelsa populations is the survival of existing trees, particularly those nearing reproductive size and those that are already producing.

\section{Sustainability indicators of the environmental dimension}

Table 4 shows the environmental indicators and the assessment results for four Brazil nut stands in Boa Água (I), Morada Nova (II), São José (III), and Encontro (IV).

For the four Brazil nut stands, the environmental indicator with the lowest score was "annual variation in the production of Brazil nuts", due to a $30 \%$ drop in the production of the crop evaluated in relation to the average for the region. Therefore, this indicator represents an undesirable condition for the sustainability of the activity.

Although the annual fluctuations in fruit production are characteristic of the species already well known by harvesters, production drops in recent years were discrepant and never experienced even by older harvesters, especially in the 2016/2017 harvest.

Brazil nut harvesters attribute these drops to changes in the frequency of rains, hindering nut formation.

Extreme weather events have become more frequent in southwestern Amazon and the years 2005, 2010, and 2016 registered the most severe droughts, causing forest fires in thousands of hectares, increasing air pollution and causing significant economic losses (Oliveira et al., 2017).

Staudhammer et al. (2021) state that the variation in Brazil nut fruit production in Acre State has also been affected by aspects related to soil characteristics, vegetative competition, higher temperatures in the dry season, and pressure deficit of water vapor in the air.

The population dynamics of Brazil nut trees and interactions with pollinators and dispersers showed favorable results, rated between "acceptable" and "ideal" conditions, demonstrating a positive correlation regarding the attributes of stability, resilience, and reliability for the management system studied.

In relation to the "deforestation" indicator, two sites evaluated are within the limit of $10 \%$ of areas open for agricultural use, according to the regulations for use of RESEX Chico Mendes (acceptable condition), while the others are configured as an "ideal" condition with less than $10 \%$ of deforested area. In this community, deforestation is not a critical problem as in other regions of this RESEX, with a tendency 
toward "pecuarization" (Gomes et al., 2012; Fittipaldy, 2017; Mascarenhas et al., 2018).

Comparison to other case studies carried out in tropical forest areas using the MESMIS method shows that the indicators defined for the environmental dimension are aligned with aspects generally monitored in studies on forest management systems and family agroecosystems (Silva et al., 2013; Proença and Massaroto, 2018; Roboredo et al., 2018).

\section{Sustainability indicators of the technical-economic dimension}

The indicators related to "Best management practices for Brazil nut" were considered strategic by all interviewees, as nut quality depends on the adoption of this set of actions. Having a product free from aflatoxins contamination is a matter of food safety, which is strongly related to the sustainability of the activity. Since the main challenge related to the quality of Brazil nuts is the high presence of contamination levels by aflatoxins, a mycotoxin produced by fungi of the genus Aspergillus.

Most indicators evaluated in the technical-economic dimension received scores from 5 to 10 , representing reference values between "acceptable" and "ideal" conditions. Only the indicator "marketing channels" revealed an undesirable situation for the good management of Brazil nut trees. Table 5 presents the results for the four Brazil nut trees studied.

Most indicators evaluated are related to the theme of best management practices (BMP) in Brazil nut harvests, representing the set of techniques adopted in the pre-harvest, harvest, and post-harvest stages to ensure production quality, species conservation, and maintenance of productive activity over time.

The scores from these indicators demonstrate that the stands evaluated almost entirely adopt the guidelines proposed in the manuals of best management practices, showing that the harvest stage still needs improvement.

Studies carried out at RESEX show that, despite the ease of appropriating BMP, the little adoption of these practices in the harvest and post-harvest stages is due to factors such as the non-differentiation of price for the managed product, the high competition from buyers in the triple border region (Brazil, Bolivia and Peru), the low management capacity of local associations to seek differentiated markets, and insufficient technical assistance to guide the BMP adoption and support product quality monitoring (Wadt et al., 2016; Fonseca et al., 2019).

Therefore, the aspects that limit the full adoption of BMP are directly related to marketing issues, except for the factor related to technical assistance aimed at product quality.

Conversely, points that favor the BMP adoption in the Community Porvir refer to the existence of two community warehouses and a series of family warehouses (built with resources from the Ecoforte Extrativismo project). In addition, the support of Embrapa Acre is paramount in promoting the training of several families in the community in the participatory mapping of Brazil nut trees, as well as the use of GPS in
Table 4 - Scores attributed to sustainability indicators in the environmental dimension in four Brazil nut stands in the Community Porvir, RESEX Chico Mendes - Acre State, Brazil.

\begin{tabular}{|c|c|c|c|c|c|}
\hline \multirow{2}{*}{$\mathbf{N}^{0}$} & \multirow{2}{*}{$\begin{array}{c}\text { Indicators - Environmental } \\
\text { Dimension }\end{array}$} & \multicolumn{4}{|c|}{ Brazil nut stands evaluated } \\
\hline & & I & II & III & $\mathbf{V}$ \\
\hline 1 & $\begin{array}{l}\text { Annual variation in Brazil nut tree } \\
\text { fruit production }\end{array}$ & 1 & 1 & 1 & 1 \\
\hline 2 & Distribution in size classes & 10 & 5 & 5 & 5 \\
\hline 3 & $\begin{array}{l}\text { Occurrence of native } \\
\text { bees and pollinators }\end{array}$ & 5 & 10 & 5 & 5 \\
\hline 4 & Occurrence of Brazil nuts dispersers & 5 & 10 & 10 & 10 \\
\hline 5 & Deforestation & 10 & 5 & 10 & 5 \\
\hline \multirow[t]{2}{*}{6} & Regeneration of Brazil nut tree & 10 & 10 & 10 & 10 \\
\hline & Final average & 6.83 & 6.83 & 6.83 & 6.00 \\
\hline
\end{tabular}

Source: elaborated by the authors from data collected in the research.

Table 5 - Scores attributed to the sustainability indicators of the technicaleconomic dimension in four Brazil nut stands evaluated in Community Porvir, RESEX Chico Mendes, Acre State, Brazil.

\begin{tabular}{|c|c|c|c|c|c|}
\hline \multirow{2}{*}{$N^{*}$} & Indicators - Technical-Economic & \multicolumn{3}{|c|}{ Brazil nut stands evaluated } \\
\cline { 5 - 7 } Dimension & I & II & III & V \\
\hline 7 & $\begin{array}{c}\text { Best pre-harvest practices: mapping } \\
\text { Brazil nut trees and production } \\
\text { estimation. }\end{array}$ & 10 & 10 & 10 & 10 \\
\hline 8 & $\begin{array}{c}\text { Best harvest practices: harvest } \\
\text { planning, recording annual } \\
\text { production of trees. }\end{array}$ & 5 & 10 & 10 & 5 \\
\hline 9 & $\begin{array}{c}\text { Best post-harvest practices: storage } \\
\text { conditions }\end{array}$ & 10 & 10 & 10 & 10 \\
\hline 10 & $\begin{array}{c}\text { Brazil nut trees maintenance } \\
\text { Marketing channels }\end{array}$ & 10 & 10 & 10 & 10 \\
\hline 11 & 5 & 5 & 1 & 1 \\
\hline 12 & Income from nuts & 10 & 10 & 10 & 10 \\
\hline & Final average & 8.33 & 9.17 & 8.50 & 7.67 \\
\hline
\end{tabular}

Source: elaborated by the authors from data collected in the research.

the inventory of trees, and in best practices of collecting, storing, and transporting the nut.

The assessment of sales channels revealed a critical situation, configured as non-favorable for the activity sustainability, as it reflects the dependence of the community on intermediaries. According to harvesters, access to differentiated markets through the adoption of new marketing strategies and the organization of production is positive for the community, as this access could provide opportunities for new so- 
cial gains, such as work and income generation for young people and women in the processing of nut-based products.

Over the past two years, association members and the community have received training in marketing and institutional markets, as well as participated in exchanges with other cooperatives. These actions stimulated reflection and discussion about new collective alternatives for marketing and adding value to the product.

The evaluation of the indicator "income from nuts" obtained the highest score, justified by the fact that the financial income obtained from the product sale accounts for more than $40 \%$ of the annual income of harvesters' families participating in the study. This reinforces the important role that Brazil nut management plays in supporting the livelihood of thousands of Amazonian residents.

\section{Sustainability indicators of the social dimension}

Table 6 shows that most indicators evaluated for the social dimension are situated between "acceptable" and "ideal" conditions, with the exception of the indicator "presence of support institutions", which had the lowest reference score for one of the participating families. For this dimension, the group represented in the evaluation workshop reflects the sample of families most involved with the association and the collective activities as a whole.

All families considered an "acceptable" level for the "access to information" indicator, since the community already has mobile telephones through a rural antenna and TV signal, although radio continues to be the main means of communication. The community has also benefited from several training courses in recent years.

The sharing of work and family income was considered "ideal" for three families and "acceptable" for one. Women participation is considered a strength for this community. The information is confirmed by the PDC (Acre, 2012), which indicated the engagement of women in decision-making, production tasks, and community activities.

\begin{tabular}{|c|c|c|c|c|c|}
\hline \multirow{2}{*}{$\mathbf{N}^{\circ}$} & \multirow{2}{*}{ Indicators - Social Dimension } & \multicolumn{4}{|c|}{ Brazil nut stands evaluated } \\
\hline & & I & II & III & V \\
\hline 13 & Access to information & 5 & 5 & 5 & 5 \\
\hline 14 & Sharing work and family income & 10 & 10 & 5 & 10 \\
\hline 15 & Social Organization & 5 & 10 & 10 & 10 \\
\hline 16 & $\begin{array}{c}\text { Knowledge about the proper use of } \\
\text { RESEX }\end{array}$ & 5 & 5 & 10 & 5 \\
\hline 17 & Fair price & 10 & 5 & 5 & 5 \\
\hline \multirow[t]{2}{*}{18} & Presence of support institutions & 5 & 5 & 1 & 5 \\
\hline & Final average & 6.67 & 6.67 & 6.00 & 6.67 \\
\hline
\end{tabular}

Source: elaborated by the authors from data collected in the research.
Likewise, the indicator "social organization" was considered "ideal" for three families and "acceptable" for one, revealing the active engagement of the harvesters participating in the study, both in the association and in other community activities. The survey carried out during the PDC (Acre, 2012) showed that 28 of the 36 families in the community were members of the association, equivalent to $77.7 \%$.

As for "knowledge about the proper use of the RESEX", only one family claimed to know all the existing regulations and management instruments, while three families claimed to know only one of the regulations (Use Plan). Farias (2013) reported a similar situation in a study carried out with representatives of 23 base centers of the RESEX, which revealed that $96 \%$ of respondents knew about the Use Plan for this Conservation Unit while $87 \%$ said they did not know the Management Plan nor the difference between this regulation and the Use Plan.

The indicator "fair price" was considered "acceptable" (price that remunerates only the labor and cost for extracting the nut) by three families and ideal for one family (price that pays environmental service and role of harvesters in addition to labor and production cost). This result demonstrates that most harvesters consider that the price paid for Brazil nuts still does not remunerate other socio-environmental services associated to forest conservation. According to Angelo et al. (2013), the price of Brazil nuts in the domestic market is determined by a series of variables, namely nut production, income, exchange rate, road network, and deforestation rate. However, Acre State has no governmental program for the payment of environmental services or state subsidies, as observed for latex production. Rubber tappers in Acre receive incentives via a government subsidy paid per kg of rubber produced (Law Chico Mendes No. 1.277 of January 13th, 1999) and also an additional amount via international payment for environmental service programs linked to the reduction of emissions by avoided deforestation (REDD).

The indicator "presence of support institutions" received scores between "undesirable" and "acceptable" conditions. There is no ongoing technical assistance for families at RESEX. Some services in Technical, Social, and Environmental Assistance (Assistência Técnica, Social e Ambiental - ATES) have already been provided with Brazilian Colonization and Land Reform Agency (Instituto Nacional de Colonização e Reforma Agrária - INCRA) resources, but in a discontinued manner.

Radial graphics have been widely used to integrate results of research involving participatory evaluation, as they allow an easy-to-understand presentation of results (Masera et al., 1999; Comin et al., 2016). This type of graphical representation shows the problems and potentialities of the management system in an integrated manner, considering each axis where the indicators selected for evaluation are found. Values closer to the outside of the graph represent aspects closer to the ideal condition.

Figure 6 presents a radial chart with the results of all indicators and dimensions evaluated for native Brazil nut trees in the Community Porvir. 


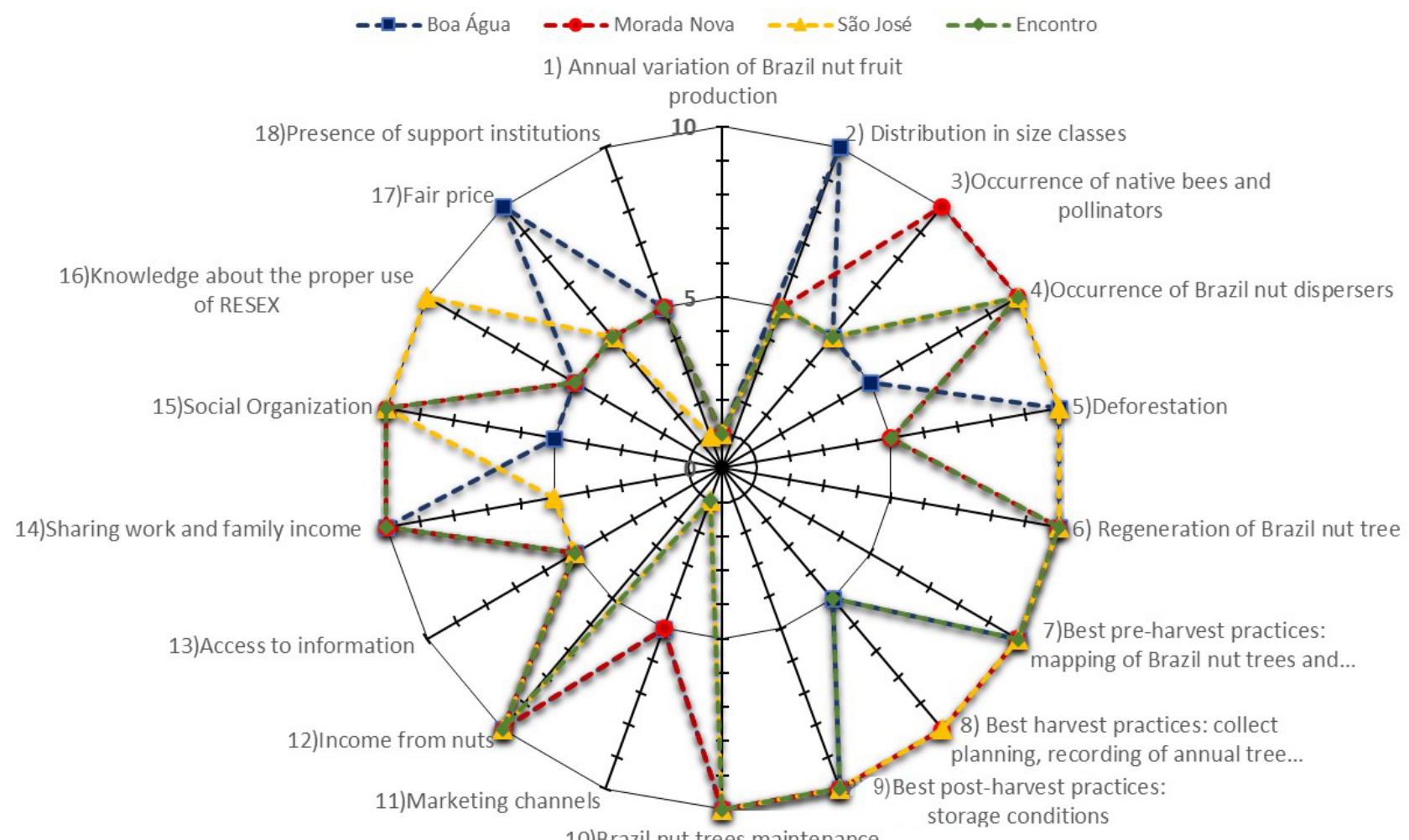

Figure 6 - Integration of the evaluation results of indicators for four native Brazil nut stands in the Community Porvir, RESEX Chico Mendes - Acre State, Brazil. Source: prepared by the author based on data collected in the research.

\section{Conclusions}

The creation of a framework of indicators, built with the collaboration of community, based on the MESMIS method associated with other participatory research tools, allowed the articulation of knowledge (traditional and scientific) and the construction of a set of 18 strategic sustainability indicators (including evaluation parameters) with easy access to harvesters.

The set of indicators built, contemplating the environmental, technical-economic, and social dimensions, as well as different sustainability attributes, showed good applicability for participatory evaluations in the context of the management system studied.

The research sampling is reduced (only one community and only one evaluation cycle), which can be a limiting factor to infer about the viability of this set of indicators to monitor sustainability of the native Brazil nut management in different situations and scales. Nevertheless, the indicators evaluated serve as a basis for building similar processes in other communities, considering the local specificities of each management system and the dialog with harvesters.

General recommendations to improve sustainability of the systems studied are:
- Long-term research to better understand factors that affect production of Brazil nut trees and recommend silvicultural practices to improve production;

- Search for partnerships, projects, and/or learning processes to increase the management capacity of the local association and aggregate product value and differentiation, and seek differentiated markets;

- Community organization to define commercialization strategies that are beneficial to the community and to guarantee the full adoption of best management practices, achieving quality standards for nuts that favor access to differentiated markets.

\section{Acknowledgments}

The authors wish to thank the harvesters who live in Community Porvir/RESEX Chico Mendes for embracing this research, for the partnership, and participation in the development of the study. We are also grateful to Embrapa, which made this research feasible through the corporate graduate program. We also thank Universidade Federal de Santa Catarina (UFSC) for providing all the necessary structure to carry out the Master's Dissertation, which originated this article. Finally, we thank ICMBio for granting the authorization to carry out the study. 


\section{Contribution of authors:}

Fonseca, F.L.: Conceptualization, Methodology, Validation, Formal Analysis, Investigation, Resources, Data Curation, Writing - Original Draft. Rover, J.O.: Conceptualization, Methodology, Validation, Formal Analysis, Investigation, Resources, Supervision, Writing - Original Draft. Wadt, L.H.O.: Methodology, Validation, Formal Analysis, Investigation, Visualization, Writing - Review \& Editing. Cartaxo, C.B.C: Methodology, Validation, Formal Analysis, Investigation, Resources. Supervision, Visualization, Writing — Review \& Editing.

\section{References}

Acre. 2012. Secretaria de Estado de Meio Ambiente do Acre. Plano de Desenvolvimento Comunitário (PDC) - Comunidade Porvir. Epitaciolândia, 82 pp.

Angelo, H.; Almeida, A.N.; Calderon, R.A.; Pompermayer, R.S.; Souza, A.N., 2013. Determinantes do preço da castanha-do-Brasil (Bertholletia excelsa) no mercado interno brasileiro. Scientia Forestalis (IPEF), v. 41, (98), 195-203 (Accessed July 27, 2018) at: https://www.ipef.br/publicacoes/scientia/nr98/ cap05.pdf.

Astier, M.; García-Barrios, L.; Galván-Miyoshi, Y.; González-Esquivel, C.; Masera, O.R., 2012. Assessing the sustainability of small farmer natural resource management systems. A critical analysis of the MESMIS program (1995-2010). Ecology and Society, v. 17, (3). http://dx.doi.org/10.5751/ES04910-170325.

Astier, M., Hollands, J., 2007. Sustentabilidad y campesinado. Seis experiencias agroecológicas en Latinoamérica. 2. ed. Mundiprensa-GIRA-ILEIA, Ciudad de México.

Bellen, H.M., 2006. Indicadores de Sustentabilidade: uma análise comparativa. 2. ed. FGV, Rio de Janeiro, 256 pp.

Bertwell, T.D.; Kainer, K.A.; Cropper, W.P. Jr.; Staudhammer, C.L.; Wadt, L.H.O., 2018. Are Brazil nut populations threatened by fruit harvest? Biotropica, v. 50, (1), 50-59. http://dx.doi.org/10.1111/btp.12505.

Brose, M.E., 2016. Cadeias produtivas sustentáveis no desenvolvimento territorial: a castanha na Bolívia e no Acre. Interações, Campo Grande, v. 17, (1), 77-86. https://doi.org/10.20435/1518-70122016108.

Cândido, G.A.; Nóbrega, M.M.; Figueiredo, M.T.E.; Souto Maior, M.M., 2015. Avaliação da sustentabilidade de unidades de produção agroecológicas: um estudo comparativo dos métodos Idea e Mesmis. Ambiente \& Sociedade, v. 18, (3), p. 99-120. http://dx.doi.org/10.1590/1809-4422ASOC756V1832015.

Caporal, F.R.; Nogueira, R.S.; Silva, D.S., 2010. Agroecologia: superar o discurso ecotecnocrático na busca de indicadores de sustentabilidade. In: Ferreira, J.M.L.; Alvarenga, A. de P.; Santana, D.P.; Vilela, M.R. (Eds.), Indicadores de sustentabilidade em sistemas de produção agrícola. Epagri, Belo Horizonte, pp. 47-86.

Cartaxo, C.B.C.; Souza, J.M.L; Wadt, L.H.O; Alvares, V.S.; Fonseca, F.L., 2016. O papel de comunidades tradicionais na definição de políticas públicas de promoção da cadeia produtiva de castanha-do-brasil. Diálogo de Saberes: Relatos da Embrapa. In: Dias, T.; Eidt, J.S.; Udry, C. (Eds.). Coleção Povos e Comunidades Tradicionais. Embrapa, Brasília, pp. 301-311. v. 2.

Comin, J.j; Fayad, J.A.; Kurtz, C.; Mafra, A.L.; Curmi, P., 2016. Guia prático de avaliação participativa da qualidade do solo em sistema de plantio direto de hortaliças (SPDH). Open Brasil Gráfica e Editora, Florianópolis. (Comunicado Técnico).

Duchelle, A.; Zambrano, A.M.; Wunder, S.; Boerner, J.; Kainer, K.A., 2014. Smallholder specialization strategies along the forest transition curve in Southwestern Amazonia. World Development, v. 64, (Suppl. 1), S149-S158. http://dx.doi.org/10.1016/j.worlddev.2014.03.001.
Empresa Brasileira de Pesquisa Agropecuária - EMBRAPA. 2017. Boletim do arranjo de projetos tecnologias para o fortalecimento da cadeia de valor da castanha-do-brasil, da Empresa Brasileira de Pesquisa Agropecuária (Embrapa). EMBRAPA, Brasil (Accessed September 28, 2017) at: https://www. embrapa.br/busca-de-noticias/-/noticia/26131296/pesquisa-aponta-queda-de70-na-producao-de-castanha-da-amazonia.

Farias, M.S., 2013. Percepção dos atores envolvidos no monitoramento do plano de manejo da Reserva Extrativista Chico Mendes, Acre, Brasil. Monography, Universidade Federal do Paraná e Universidade Federal do Acre, Rio Branco.

Fonseca, F.L.; Cartaxo, C.B.C.; Wadt, L.H.O., 2019. Challenges in adopting good management practices for sustainable extraction of Brazil nuts in Acre, Brazil. In: XXV IUFRO World Congress, 2019, Curitiba. Pesquisa Florestal Brasileira. Embrapa, Curitiba, pp. 527-527. v. 39.

Fittipaldy, M.C.P.M., 2017. Reserva Extrativista Chico Mendes: dos empates à pecuarização? Edufac, Rio Branco (Accessed December 8, 2019) at: http:// www2.ufac.br/editora/livros/reserva-extrativista-chico-mendes.pdf.

Gallopín, G.C., 1996. Environmental and sustainability indicators and the concept of situational indicators: a system approach. Environmental Modelling \& Assessment, v. 1, (3), 101-117. https://doi.org/10.1007/BF01874899.

Gardner, T.; Costi, H.T., 2014. Carta do Editor. Boletim do Museu Paraense Emilio Goeldi. Ciências Naturais, Belém, v. 9, (2).

Gomes, C.V.A.; Perz, S.G.; Vadjunec, J.M., 2012. Convergence and contrasts in the adoption of cattle ranching: Comparisons of smallholder agriculturalists and forest extractivists in the Amazon. Journal of Latin American Geography, v. 11, (1), 99-120. https://doi.org/10.1353/lag.2012.0018.

Gomes, J.C.C., 2010. As técnicas participativas na pesquisa agrícola: fundamentos teóricos e algumas dificuldades práticas. In: Brose, M. (Ed.), Metodologia participativa: uma introdução a 29 instrumentos. 2. ed. Tomo Editorial, Porto Alegre, pp. 307-314.

Hammond, A.; Adriaanse, A.; Rodenburg, E.; Bryant, D.; Woodward, R., 1995. Environmental indicators: a systematic approach to measuring and reporting on environmental policy performance in the context of sustainable development. World Resources Institut, Washington, D.C.

Kainer, K.A.; Wadt, L.H.O.; Staudhammer, C.L., 2018. The evolving role of Bertholletia excelsa in Amazonia: contributing to local livelihoods and forest conservation. Desenvolvimento e Meio Ambiente, v. 48, (1), 477-497. https:// doi.org/10.5380/dma.v48i0.58972.

López-Ridaura, S.; Masera, O.; Astier, M., 2002. Evaluating the sustainability of complex socio-environmental systems. the MESMIS framework. Ecological Indicators, v. 2, (1-2), 135-148. https://doi.org/10.1016/S1470-160X(02)00043-2.

Loureiro, J.P.B.; Santos, M.A.S.; Rodrigues, H.E.; Souza, C.C.F.; Rebello, F.K., 2020. Avaliação de sistemas de manejo de recursos naturais com base em indicadores de sustentabilidade: uma revisão sistemática da literatura sobre o uso do método MESMIS. Research, Society and Development, v. 9, (8), e538986067. http://dx.doi.org/10.33448/rsd-v9i8.6067. 
Marques, J.F.; Skorupa, L.A.; Ferraz, J.M.G., 2003. (Ed.). Indicadores de sustentabilidade em agroecossistemas. Embrapa Meio Ambiente, Jaguariúna, $281 \mathrm{pp}$.

Mascarenhas, F.S.; Brown, I.F.; Silva, S.S., 2018. Deforestation and forest fires transforming the reality of the Chico Mendes Extractive Reserve. Desenvolvimento e Meio Ambiente, v. 48, 236-262. https://doi.org/10.5380/ dma.v48i0.58826.

Masera, O.; Astier, M.; López-Ridaura, S., 1999. Sustentabilidad y manejo de recursos naturales: el marco de evaluación MESMIS. Mundi-Prensa, México, 109 pp.

Masera, O; Lopez-Riadura S. (org.). Sustentabilidad y Sistemas Campesinos: cinco experiencias de evaluaciónenel México rural. México: Mundi-Prensa, 346 p., 2000

Melane-Lavado, A.; Álvarez-Herranz, A., 2018. Different ways to access knowledge for sustainability-oriented innovation. The effect of foreign direct investment. Sustainability (Switzerland), v. 10, (11), 4206. https://doi. org/10.3390/su10114206.

Oliveira, I.D.; Brown, I.F.; Silva, S.S., 2017. Geotecnologias e mídia social como ferramentas para alerta de eventos climáticos extremos: exemplo da seca de 2016 na Amazônia Sul-ocidental. In: XVIII Simpósio Brasileiro de Sensoriamento Remoto-SBSR, 2017, Santos. INPE, São Jose dos Campos, pp. 7126-7133.

Peres, C.A.; Baider, C.A.; Zuidema, P.A.; Wadt, L.H.O.; Kainer, K.A.; GomesSilva, D.A.P.; Salomão, R.P.; Simões, L.L.; Franciosi, E.R.N.; Valverde, F.C.; Gribel, R.; Shepard Jr., G.H.; Kanashiro, M.; Coventry, P.; Yu, D.W.; Watkinson, A.R.; Freckleton, R.P., 2003. Demographic Threats to the sustainability of Brazil nut exploitation. Science, v. 22, (1091698), 2112-2114. http://dx.doi. org/10.1126/science.1091698.

Picanço, C.A.S.; Costa, R.C., 2019. Análise da cadeia produtiva da castanhado-Brasil coletada na reserva biológica do Rio Trombetas, Oriximiná, Pará. Brazilian Journal of Development, v. 5, (10), 19460-19483. http://dx.doi. org/10.34117/bjdv5n10-170

Proença, I.C.L.; Massaroto, J.A., 2018. Estudo da sustentabilidade em agroecossistemas orgânicos na Amazônia mato-grossense, Brasil. ELO Diálogos em Extensão, v. 7, (2), 15-27. http://dx.doi.org/10.21284/elo.v7i2.1257.

Ribeiro, M.B.N.; Jerozolimski, A.; Robert, P.; Salles, N.V.; Kayapó, B.; Pimentel, T.P.; Magnusson, W.E., 2014. Anthropogenic landscape in Southeastern Amazonia: Contemporary impacts of low-intensity harvesting and dispersal of brazil nuts by the Kayapó indigenous people. Plos One, v. 9, (7), e102187. http://dx.doi.org/10.1371/journal.pone.0102187.

Roboredo, D.; Bergamasco, S.M.P.P.; Ara, A.; Gervázio, W.; Domingues, T.R., 2018. Clusterizacão de sistemas de manejos e a construção de indicadores de sustentabilidade utilizando a metodologia MESMIS. RA'E GA - O Espaço Geográfico em Análise, v. 43, 23-42. http://dx.doi.org/10.5380/raega. v43i0.48787.

Schlindwein, S.L., 2010. Indicadores de sustentabilidade e aprendizagem social. In: Ferreira, J.M.L.; Alvarenga, A.P.; Santana, D.P.; Vilela, M.R. (Eds.), Indicadores de sustentabilidade em sistemas de produção agrícola. EPAMIG, Belo Horizonte, pp. 87-106.

Scoles, R.; Gribel, R., 2011. Population structure of Brazil Nut (Bertholletia excelsa, Lecythidaceae) stands in two areas with different occupation histories in the Brazilian Amazon. Human Ecology, v. 39, 455-464. http://dx.doi. org/10.1007/s10745-011-9412-0.
Scoles, R.; Gribel, R., 2015. Human Influence on the Regeneration of the Brazil Nut Tree (Bertholletia excelsa Bonpl., Lecythidaceae) at Capanã Grande Lake, Manicoré, Amazonas, Brazil. Human Ecology, v. 43, (6), 843-854. http://dx.doi org/10.1007/s10745-015-9795-4

Silva, L.M.S.; Resque, A.G.L.; Feitosa, L.L.; Nogueira, A.C.N., 2013. Avaliando a sustentabilidade de agroecossistemas familiares: adaptando o MESMIS para distintos contextos da Amazônia brasileira. In: IV Congresso Latino-americano de Agroecologia - Universidad Nacional Agraria La Molina, Lima, 16 pp.

Silva, T.P.; Pontes, A.N.; Albuquerque, A.R., 2020. Cadeias de produção sustentáveis no extrativismo de castanha do Brasil na Amazônia brasileira. Brazilian Journal of Development, v. 6, (8), 63460-63478. http://dx.doi. org/10.34117/bjdv6n8-687.

Simoni, J.S., 2009. A multidimensionalidade da valorização de produtos locais: implicações para políticas públicas, mercado, território e sustentabilidade na Amazônia. Doctoral Thesis, Centro de Desenvolvimento Sustentável, Universidade de Brasília, Brasília.

Staudhammer, C.L.; Wadt, L.H.O.; Kainer, K.A.; Cunha, T.A., 2021. Comparative models disentangle drivers of fruit production variability of an economically and ecologically important long-lived Amazonian tree. Scientific Reports, v. 11, 2563. https://doi.org/10.1038/s41598-021-81948-4.

Steenbock, W.; Silva, R.O.; Seoane, C.E.; Froufe, L.C.M.; Braga, P.C.; Silva, R.M., 2013. Geração e uso de indicadores de monitoramento de agrofloresta por agricultores associados a Cooperafloresta. In: Steenbock, W.; Costa e Silva, L.; Silva, R.O.; Rodrigues, A.S.; Perez-Cassarino, J.; Fonini, R. (Eds.), Agrofloresta, ecologia e sociedade. Kairós, Curitiba, pp. 305-320.

Vivan, J.L.; Floriani, G.S., 2001. Construção participativa de indicadores de sustentabilidade em sistemas agroflorestais em rede na Mata Atlântica. In: Congresso Brasileiro de Sistemas Agroflorestais, 5., 2001, Curitiba. SAFs: desenvolvimento com proteção ambiental: anais. Embrapa Florestas, Colombo, pp. 134-139.

Wadt, L.H.O.; Kainer, K.A.; Gomes-Silva, D.A.P., 2005. Population structure and nut yield of a Bertholletia excelsa stand in Southwestern Amazonia. Forest Ecology and Management, v. 211, (3), 371-384. http://dx.doi.org/10.1016/j. foreco.2005.02.061

Wadt, L.H.O.; Kainer, K.A.; Staudhammer, C.L.; Serrano, R.O.P., 2008. Sustainable forest use in Brazilian extractive reserves: natural regeneration of Brazil nut in exploited populations. Biological Conservation, v. 141, (1), 332346. http://dx.doi.org/10.1016/j.biocon.2007.10.007.

Wadt, L.H.O.; Passetti, A.M.R.S.; Pereira, V.A.M.; Fonseca, F.L.; Alvares, V.S.; Cartaxo, C.B.C.; Souza, J.M.L., 2016. Experiência de adoção de boas práticas de manejo para o extrativismo sustentável da castanha-do-brasil em duas comunidades extrativistas da Resex Chico Mendes, Acre. Diálogo de Saberes: Relatos da Embrapa. In: Dias, T.; Eidt, J.S.; Udry, C. (Eds.), Coleção Povos e Comunidades Tradicionais. Embrapa, Brasília, pp. 289-300. v. 2.

Walker, W.S.; Gorelik, S.R.; Baccini, A.; Aragon-Osejo, J.L.; Josse, C.; Meyer, C.; Macedo, M.N.; Augusto, C.; Rios, S.; Katan, T.; Souza, A.A.; Cuellar, S.; Llanos, A.; Zager, I.; Mirabal, G.D.; Solvik, K.K.; Farina, M.K.; Moutinho, P.; Schwartzman, S., 2020. The role of forest conversion, degradation, and disturbance in the carbon dynamics of Amazon indigenous territories and protected areas. Proceedings of the National Academy of Sciences of the United States of America, v. 117, (6), 3015-3025. https://doi.org/10.1073/pnas.1913321117.

Zuidema, P.A.; Boot, R.G.A., 2002. Demography of the Brazil nut tree (Bertholletia excelsa) in the Bolivian Amazon: impact of seed extraction on recruitment and population dynamics. Journal of Tropical Ecology, v. 18, (1), 1-31. http://dx.doi.org/10.1017/S0266467402002018. 